\title{
Effect of Zinc and Boron on Growth, Yield and Quality of Onion (Allium cepa L.) cv. Agrifound Dark Red
}

\author{
Khatemenla $^{1 *}$, V.B. Singh ${ }^{2}$, Trudy Tengse A. Sangma ${ }^{1}$ and C.S. Maiti ${ }^{2}$ \\ ${ }^{1}$ Department of Horticulture, Assam Agricultural University, Jorhat-785013, India \\ ${ }^{2}$ Department of Horticulture, School of Agricultural Sciences and Rural Development, \\ Medziphema-797106, India \\ *Corresponding author
}

\section{A B S T R A C T}

Studies on effect of zinc and boron on growth, yield and quality of onion cv. Agrifound Dark Red was carried out with nine treatment (zinc viz., 0,25 and $50 \mathrm{~kg} / \mathrm{ha}$ and boron viz.,

\section{Keywords}

Boron, Growth, Quality, Yield, Zinc

Article Info

Accepted:

30 March 2018

Available Online:

10 April 2018
$0,2.5$ and $5 \mathrm{~kg} / \mathrm{ha}$ ) combinations. Results were significant in most of the parameters. The highest plant height $(57.47 \mathrm{~cm})$, number of leaves $(12.37)$, neck thickness $(1.68 \mathrm{~cm})$, bulb diameter $(6.83 \mathrm{~cm})$, bulb weight $(110.80 \mathrm{~g})$, yield plot $^{-1}(5.32 \mathrm{~kg})$, yield hectare ${ }^{-1}(236.59$ q), dry weight of bulb (14.30 g), total soluble solids (TSS) $(13.98 \%)$, Zn content in leaves (41.27 ppm) and bulbs (55.33 ppm), B content in leaves (13.87 ppm) and bulbs (14.43 ppm), N (1.49\%), P (0.58\%) and K (1.77\%) content in leaves and N (1.60\%), P (0.47\%) and $\mathrm{K}(1.85 \%)$ content in bulbs were maximum in treatment combination of $\mathrm{Zn} 25 \mathrm{~kg}+\mathrm{B}$ $5 \mathrm{~kg} \mathrm{ha}^{-1}$, while treatment combination of $\mathrm{Zn} 50 \mathrm{~kg}+\mathrm{B} 5 \mathrm{~kg} \mathrm{ha}^{-1}$ showed maximum sulphur content in leaves (2196.7 ppm) and bulbs (2344 ppm). The results clearly indicated that soil application of $\mathrm{Zn} 25 \mathrm{~kg}+$ B $5 \mathrm{~kg} \mathrm{ha}^{-1}$ significantly improved the growth, yield and quality of onion compared to other treatment combinations and control and also found economically best with benefit cost ratio $1: 4.3$.

\section{Introduction}

The onion (Allium cepa L.) belonging to the family Alliaceae is one of the most important bulbous crop of the world and the most important commercial crop grown all over the country for both spice as well as for vegetable purpose. It has medicinal and diuretic properties, relieves heat sensation, hysterical faintness, insect bites and also heart stimulation. Through many experiments conducted on onion, it has been realized that the better growth and quality and higher yield of onion can be obtained with the adequate and balanced application of both macronutrients and micronutrients under suitable agro climatic condition.

Micronutrients play an active role in the plant metabolic process from cell wall development to respiration, photosynthesis, chlorophyll formation, enzymes activity, nitrogen fixation etc. Micronutrients work as a co- enzyme for a large number of enzymes. It also plays an 
essential role in improving yield and quality and highly required for better plant growth and yield of many crops (Alam et al., 2010). Soil application of micronutrients during crop growth (onion) was successfully used for correcting their deficits and improving the mineral status of plants as well as increasing the crop yield and quality (Jawaharlal et al., 1986; Thakare et al., 2007; Ali, 2013). The onion, like any other crops not only needs macronutrients but also micronutrients in adequate and balanced amounts (Ballabh et al., 2013).

It was reported that North Eastern region of India is deficient of zinc whose deficiency causes yellowing of leaves in onion. Bolting is also reported to be a problem in onion cultivation which is due to deficiency of boron. In Nagaland condition, some cultivars like Arka Kalayayan, N-53 and Agrifound Dark Red were tested during kharif season and out of which Agrifound Dark Red was found to be most suitable under Medziphema condition.

The use of micronutrients should be made with great caution because of their small amounts needed and interactions with other nutrients. Improvement in onion growth and yield has been reported through micronutrient by many scientists at different types of soils. But very little information is available on these aspects under sub-tropical foothill conditions. Keeping in view, the experiment was undertaken.

\section{Materials and Methods}

\section{Location}

The experimental farm is located at the foothills of Nagaland at an altitude of $310 \mathrm{~m}$ above mean sea level, with the geographical location of $25^{\circ} 45^{\prime \prime} 43^{\prime} \mathrm{N}$ latitude and $95^{\circ}$ 53 "04' E longitude.

\section{Fertilizer application}

Bulbs were planted at a spacing of $15 \mathrm{~cm} \mathrm{x} 15$ $\mathrm{cm}$ in a plot size of $1.5 \mathrm{~m}$ x $1.5 \mathrm{~m}$. FYM @ 25 $\mathrm{t} \mathrm{ha}^{-1}$ along with N, P and K @ 100:60:60 kg $\mathrm{ha}^{-1}$, respectively and was applied uniformly in all experimental plots in the form of urea, single super phosphate (SSP) and Muriate of Potash (MOP). Urea and MOP was applied in two split doses i.e., at the time of land preparation and second dose 30 days after planting.

\section{Treatment}

The experimental field was laid in randomized block design (RBD) with two factors. These were:

\section{Factor A}

There were three levels of zinc as follows. The source of zinc was zinc sulphate $\left(\mathrm{Zn}_{2} \mathrm{SO}_{4}\right)$

$\mathrm{Zn}_{0}=0 \mathrm{~kg} \mathrm{Zn} \mathrm{ha}$
$\mathrm{Zn}_{1}=25 \mathrm{~kg} \mathrm{Zn} \mathrm{ha}^{-1}$
$\mathrm{Zn}_{2}=50 \mathrm{~kg} \mathrm{Zn} \mathrm{ha}^{-1}$

\section{Factor B}

There were three levels of boron as follows. The source of boron was boric acid $\left(\mathrm{H}_{3} \mathrm{BO}_{3}\right)$

$\mathrm{B}_{0}=0 \mathrm{~kg} \mathrm{ha}^{-1}$
$\mathrm{~B}_{1}=2.5 \mathrm{~kg} \mathrm{ha}^{-1}$
$\mathrm{~B}_{2}=5 \mathrm{~kg} \mathrm{ha}^{-1}$

\section{Treatment combination}

$\mathrm{T}_{1}-\mathrm{Zn}_{0}+\mathrm{B}_{0}$

$\mathrm{T}_{2}-\mathrm{Zn}_{0}+\mathrm{B}_{1}$

$\mathrm{T}_{3}-\mathrm{Zn}_{0}+\mathrm{B}_{2}$

$\mathrm{T}_{4}-\mathrm{Zn}_{1}+\mathrm{B}_{0}$

$\mathrm{T}_{5}-\mathrm{Zn}_{1}+\mathrm{B}_{1}$

$\mathrm{T}_{6}-\mathrm{Zn}_{1}+\mathrm{B}_{2}$

$\mathrm{T}_{7}-\mathrm{Zn}_{2}+\mathrm{B}_{0}$ 
$\mathrm{T}_{8}-\mathrm{Zn}_{2}+\mathrm{B}_{1}$

$\mathrm{T}_{9}-\mathrm{Zn}_{2}+\mathrm{B}_{2}$

\section{Growth parameters}

During the initial growth stage randomly five plants were selected to record the observations on plant height and number of leaves per plant. Plant height was measured with the help of meter scale. The number of leaves per plant was counted from five sample plants of each plot at 15 days interval to observe the rate of growth and their average was taken as number of leaves per plant.

The number of bolting in all the plants from each plot were recorded and continued till harvest and their average values were expressed in percentage.

After harvesting, the doubles were counted from the total bulbs of each unit plot and their percentages were calculated using the following formula:

Doubling $\%=\frac{\text { No.of doubled bulbs }}{\text { Total no.of bulbs }} \times 100$

\section{Yield and yield attributing characters}

The fresh weight of the bulb from were recorded after the harvest with the help of weighing balance and the average bulb weight for each treatment was worked out and represented in terms of gram.

Neck thickness and bulb diameter was measured with the help of Vernier calliper after harvesting. The yield per hectare in respect of various treatments was calculated by using the following formula:

$\mathrm{Y}=\mathrm{A} \times \frac{1000}{S}$

Where,
$\mathrm{A}=$ Yield per plot

$\mathrm{S}=$ Plot area

$\mathrm{Y}=$ Yield per hectare

The results obtained were expressed in quintal (q/ha).

\section{Quality parameters}

Total soluble solids were measured with the help of hand refractometer. Dry weight of leaves and bulbs was determined by keeping them in oven at $50^{\circ} \mathrm{C}$ for 73 hours for drying and weighed on electronic balance.

The concentration of zinc in leaves and bulbs was determined by using Atomic Absorption Spectrophotometer (AAS) method (Lindsay and Norwell, 1978), concentration of sulphur in leaves and bulbs was determined by using the Barium Chromate Colorimetric method (Palasker et al., 1981), concentration of boron in leaves and bulbs was determined by Azomethine - $\mathrm{H}$ method (John et al., 1975) and the data collected was calculated as part per million on dry weight basis. Similarly, Nitrogen was determined by Kjeldhal method as described by Blake (1965), Phosphorus was estimated by using Vanado Molybdate Yellow colour method (Jackson, 1967) and Potassium content was estimated by Flame- Photometry (Chapman and Pratt, 1961).

\section{Fertility status of the soil after harvest}

The soil samples were collected from five spots in each experimental plot after harvesting at a depth of $10-15 \mathrm{~cm}$ with the help of screw auger. The collected soil samples were mixed and reduced into $500 \mathrm{~g}$ and dried in shade, grounded and sieved for determination of the following nutrient status.

Organic carbon was determined by Walkey and Blake rapid titration method as described by Piper (1966). The $\mathrm{pH}$ of the soil was 
determined in 1:2 soil water suspension using model LI 120 digital meter (A.O.A.C, 1988). The available soil nitrogen $(\mathrm{N})$ was estimated by alkaline potassium permanganate method as suggested by Subbiah and Asija (1956). The available phosphorus $\left(\mathrm{P}_{2} \mathrm{O}_{5}\right)$ was determined by Bray's method (Bray and Kurtz, 1945). The available potassium $\left(\mathrm{K}_{2} \mathrm{O}\right)$ was determined by Ammonium acetate method (Hanway and Heidal, 1952).

\section{Economics of the treatment}

Economics of the different treatments were worked out according to prevailing market prices of inputs and outputs. The cost of cultivation was calculated as per the item wise as well as treatment wise cost incurred in each treatment.

\section{Gross income}

Gross income was calculated by multiplication of yield and the selling rate of onion.

\section{Net income}

Net income was estimated by deducting the total cost of cultivation (fixed cost + treatment cost) from gross income of the particular treatment.

\section{Benefit cost ratio}

Benefit cost ratio was calculated by the formula:

Benefit cost ratio $=\frac{\text { total output }}{\text { total input }}$

\section{Method of analysis}

The data recorded during the course of investigation were statistically analyzed by the analysis of variance method (Panse and Sukhatme, 1978) and the significance of different sources of variation were tested by error mean square using Fisher Schedecor ' $F$ ' test of probability of $5 \%$ level of significance.

\section{Results and Discussion}

An examination of the data presented in table 1 , strongly showed that there was a significant effect of soil application of zinc and boron on vegetative growth parameters of onion plants. Soil application of onion plants with treatment combination of $\mathrm{Zn} 25 \mathrm{~kg} \mathrm{ha}^{-1}$ and B $5 \mathrm{~kg} \mathrm{ha}^{-1}$ resulted in the highest value of vegetative growth parameters. The maximum plant height $(57.47 \mathrm{~cm})$ was recorded in treatment combination ( $\mathrm{Zn} 25 \mathrm{~kg} \mathrm{ha}^{-1}+\mathrm{B} 5 \mathrm{~kg} \mathrm{ha}^{-1}$ ) and the minimum $(39.57 \mathrm{~cm})$ under control. The maximum number of leaves (12.37 plant $^{-1}$ ) was obtained from treatment combination ( $\mathrm{Zn}$ $25 \mathrm{~kg} \mathrm{ha}^{-1}+\mathrm{B} 5 \mathrm{~kg} \mathrm{ha}^{-1}$ ) and the minimum from control (7.97 plant $\left.^{-1}\right)$. The highest neck thickness of bulbs $(1.68 \mathrm{~cm})$ at maturity stage was found in treatment combination ( $\mathrm{Zn} 25 \mathrm{~kg}$ $\left.\mathrm{ha}^{-1}+\mathrm{B} 5 \mathrm{~kg} \mathrm{ha}^{-1}\right)$ and lowest $(1.15 \mathrm{~cm})$ under control. Bolting percentage was found to be highest $(4.93 \%)$ in treatment combination $\mathrm{Zn}_{2} \mathrm{~B}_{2}\left(\mathrm{Zn} 50 \mathrm{~kg}+\mathrm{B} 5 \mathrm{~kg} \mathrm{ha}^{-1}\right)$ and lowest $(4.27 \%)$ in treatment ( $\mathrm{Zn} 25 \mathrm{~kg}+\mathrm{B} 5 \mathrm{~kg}$ $\left.\mathrm{ha}^{-1}\right)$. Doubling percentage was found to be highest $(5.60 \%)$ in treatment combination ( $\mathrm{Zn}$ $\left.50 \mathrm{~kg} \mathrm{ha}^{-1}+\mathrm{B} 5 \mathrm{~kg} \mathrm{ha}^{-1}\right)$ and lowest (4\%) in treatment (Zn $\left.25 \mathrm{~kg} \mathrm{ha}^{-1}+\mathrm{B} 2.5 \mathrm{~kg} \mathrm{ha}^{-1}\right)$.

Therefore, it was found that combination of zinc and boron plays an active role in vegetative growth of onion plant. These results are in accordance with the investigation of Alam et al., (2010), Jawaharlal et al., (1996), Ballabh et al., (2013) and Ali (2013). The favourable effect of micronutrients on plant growth might be due to its role in many physiological processes and cellular functions within the plants. In addition, they play an essential role in improving plant growth, through biosynthesis of endogenous hormones which is responsible for promoting of plant 
growth (Hansch and Mendel, 2009). These results were also reported by Ballabh et al., (2013).

Increase in growth attributes might be due to the fact that besides the role of zinc in chlorophyll formation, it also influenced cell division, meristematic activity of tissues, and expansion of cell and formation of cell wall (Chhipa, 2005). The positive effects due to application of boron also may be probably due to the beneficial effects as it helps in cell division and also increases calcium content of growing tissues thereby causing better vegetative growth. The beneficial effect of boron on growth parameters was reported by Manna et al., (2011), Chanchan et al., (2013) and Acharya et al., (2014). Therefore the combined effect of zinc and boron was found to be most superior in comparison with single effect and control. These findings also are in conformity with the findings of Manna et al., (2011), Singh et al., (2005), Quddus et al., (2009) and Alam et al., (2010), Ali (2013) and Acharya et al., (2014).

A perusal of data presented in table 2 revealed that all the treatments were found significantly superior to control. The maximum bulb diameter $(6.83 \mathrm{~cm})$ was obtained by applying $\mathrm{Zn} 25 \mathrm{~kg}+\mathrm{B} 5 \mathrm{~kg} \mathrm{ha}^{-1}$ followed by Zn $50 \mathrm{~kg}$ + B $5 \mathrm{~kg} \mathrm{ha}^{-1}(6.30 \mathrm{~cm})$. The highest of bulb weight $(110.80 \mathrm{~g})$ was recorded from the treatment combination ( $\mathrm{Zn} 25 \mathrm{~kg}+\mathrm{B} 5 \mathrm{~kg}^{-}$ ${ }^{1}$ ) and the lowest bulb weight was found in control. The highest shoot: bulb ratio $(0.48)$ was recorded from treatment combination ( $\mathrm{Zn}$ $25 \quad \mathrm{~kg}+\mathrm{B} \quad 5 \quad \mathrm{~kg}$ $\mathrm{ha}^{-1}$ ) and the lowest was found in control (0.27). Yield data presented in table 3 shows that zinc and boron produced significant variations for bulb yield of onion. The maximum bulb yield per plot $(5.32 \mathrm{~kg})$ was recorded from ( $\mathrm{Zn} 25 \mathrm{~kg}+\mathrm{B} 5 \mathrm{~kg} \mathrm{ha}^{-1}$ ) while the lowest was found in control $(2.31 \mathrm{~kg})$. Similarly the highest bulb yield per hectare
(236.59 q) was recorded in treatment (Zn 25 $\left.\mathrm{kg}+\mathrm{B} 5 \mathrm{~kg} \mathrm{ha}^{-1}\right)$ and the lowest (102.66 q) was found in control. The treatment combination ( $\mathrm{Zn} 25 \mathrm{~kg}+\mathrm{B} 5 \mathrm{~kg} \mathrm{ha}^{-1}$ ) performed as the highest yielder by 59 percent, over control.

A significant variation was found in respect of yield and yield attributing characters due to the effect of different treatments combination of zinc and boron. The yield advantages of different treatment combinations were due to better growth and development. Thus higher photosynthates accumulation in the bulbs for higher leaves per plant would ensure higher individual bulb weight, large bulb diameter and neck thickness. This might be due to the main function of zinc in plant as a metal activator of several enzymes like dehydrogenase, proteinase and peptidases (Prasad and Kumar, 2010). The beneficial effect of zinc on the yield parameters may be attributed due to the fact that soil application of zinc resulted in increased supply of the available zinc to the plants which led to proper growth and development because essential role of zinc has been established as a component of several enzymes which are concerned with carbohydrate and nitrogen metabolism, in addition to its involvement directly or indirectly in regulating the various physiological processes of plants (Marschner, 1995). The findings were in conformity with the findings of Jawaharlal et al., (1986), Khan et al., (2007), Thakare et al., (2007) and Ballabh et al., (2013).

The increase in the yield by boron application may be due to its role in enhancing the translocation of carbohydrates from the site of its synthesis to the storage tissue as boron is known to play beneficial role in the translocation of carbohydrates (Sisler et al., 1956). These results are in agreement based on experimental evidence by Mishra et al., (1990), Chermsiri et al., (1995) and Devi et 
al., (2009). More-over, applied boron and zinc in combination of nitrogen, phosphorus, potash and FYM undoubtedly increased the yield, indicating that the soil was deficient in those nutrients. Thus the interaction effect between zinc and boron was found to be most effective as compared to single dose of zinc and boron and control. These results are in congruity with works done by Halder et al., (2007), Quddus et al., (2009), Ali (2013) and Acharya et al., (2014).

The data presented in table 3 showed that there was a significant effect of soil application of zinc and boron on quality parameters of onion plant. The effects of zinc and boron on quality of onion was studied in terms of dry matter of leaves and bulbs, TSS, zinc, boron, sulphur, nitrogen, potassium, phosphorus and content in leaves and bulbs. Application of zinc and boron significantly influenced the dry weight of onion. The maximum dry weight of leaves $(17.33 \mathrm{~g})$ was recorded in $\mathrm{Zn} 50 \mathrm{~kg}+\mathrm{B} 2.5 \mathrm{~kg} \mathrm{ha}^{-1}$ while the lowest was found in control (8.60g). Dry weights of bulb (14.30 g) were observed higher in $\mathrm{Zn} 25 \mathrm{~kg}+\mathrm{B} 5 \mathrm{~kg} \mathrm{ha}^{-1}$ which gave 31.4 per cent increase in dry weight of bulbs over control $(9.80 \mathrm{~g})$. The treatment $\mathrm{Zn} 25 \mathrm{~kg}$ + B $5 \mathrm{~kg} \mathrm{ha}^{-1}$ recorded the maximum TSS of $13.98^{\mathrm{O}} \mathrm{B}$ followed by $\mathrm{Zn} 50 \mathrm{~kg} \mathrm{ha}^{-1}\left(13.11^{\mathrm{O}} \mathrm{B}\right)$ and the lowest was recorded from control $\left(9.77{ }^{\mathrm{O}} \mathrm{B}\right)$. The findings are also in collaboration with works done by Singh and Ram (2001), Srivastava et al., (2005) and Trivedi (2013) and Ballabh (2013). Ali (2013) reported that the dry matter content was recorded maximum from nutrient combination of $\mathrm{Zn} 3 \mathrm{~kg}+\mathrm{B} 2 \mathrm{~kg}+\mathrm{Mo} 1 \mathrm{~kg}+\mathrm{S} 15 \mathrm{~kg}+\mathrm{N}$ $100 \mathrm{~kg}+\mathrm{P} 35 \mathrm{~kg}+$ and $\mathrm{K} 100 \mathrm{~kg} \mathrm{ha}^{-1}$. Further, Alam et al., (2010) and Sindhu and Tiwari (1993) also reported that combination effect between zinc and boron enhanced the qualitative characters.

From the investigation it was also evident that soil application of various doses of boron not only altered the quantitative characters but also enhanced the qualitative characters like dry weight of leaves. These results are in conformity with works done by Manna et al., (2011), Hania (2012) and Devi et al., (2009). The improvement in total soluble solids (TSS) content in treated bulbs due to micronutrients might be attributed to enhance metabolic processes involved in biosynthesis of total soluble solids such as carbohydrates, organic acid, amino acids and other inorganic constituents. The enhancement in all such biochemical constituents might have caused an increase in TSS (Total soluble solids) and dry matter. This work is in relation with experiment conducted by Ballabh (2013) where he reported that $\mathrm{Zn} @ 4 \mathrm{mg} \mathrm{L}^{-1}$ gave the maximum TSS. The findings were also in relation with works done by Singh and Ram (2001), Srivastava et al., (2005) and Trivedi (2005).

Also from table 3 it is evident that the treatment $\mathrm{Zn} 25 \mathrm{~kg}+\mathrm{B} 5 \mathrm{~kg} \mathrm{ha}^{-1}$ recorded the highest zinc content in leaves (41.27 ppm) and bulbs (55.33 ppm) and also in boron content in leaves (13.87) and bulbs (14.43) while the lowest was found in control. The sulphur content in leaves (2196.7 ppm) and in bulb (2244 ppm) was found to be highest in treatment $\mathrm{Zn} 50 \mathrm{~kg}+\mathrm{B} 5 \mathrm{~kg} \mathrm{ha}^{-1}$ and the lowest was found in control. The application of zinc in soil might have increased the availability of zinc in the rhizosphere. The favourable effect of zinc on photosynthesis and metabolic processes might have augmented the production of photosynthesis and their translocation to different plant parts, which ultimately increased the concentration of nutrients in the plant. It has been observed that boron nutrition has also positively increased the concentration of both macro and micro nutrients in onion. Similar results were also reported by Mishra et al., (1990), Balyan et al., (1994), Yadav et al., (2006), Chhippa (2005) and Lal (2012). 
Table.1 Effect of zinc and boron on growth parameters of onion

\begin{tabular}{|c|c|c|c|c|c|}
\hline Treatment & $\begin{array}{c}\text { Plant } \\
\text { height (cm) }\end{array}$ & $\begin{array}{l}\text { Leaves } \\
\text { plant }^{-1}\end{array}$ & $\begin{array}{l}\text { Neck thickness } \\
\text { (cm) }\end{array}$ & $\begin{array}{c}\text { Bolting } \\
(\%)\end{array}$ & $\begin{array}{c}\text { Doubling } \\
(\%)\end{array}$ \\
\hline \multicolumn{6}{|l|}{ Zinc } \\
\hline $\mathbf{Z}_{0}$ (Control) & 42.11 & 9.84 & 1.39 & 4.46 & 4.82 \\
\hline $\mathrm{Z}_{1}\left(25 \mathrm{~kg} \mathrm{ha}^{-1}\right)$ & 52.19 & 11.87 & 1.56 & 4.42 & 4.72 \\
\hline $\mathrm{Z}_{2}\left(50 \mathrm{~kg} \mathrm{ha}^{-1}\right)$ & 49.22 & 12.34 & 1.61 & 4.47 & 4.88 \\
\hline CD at 5\% & 3.49 & 1.21 & 0.10 & 0.18 & NS \\
\hline \multicolumn{6}{|l|}{ Boron } \\
\hline $\mathbf{B}_{0}$ (Control) & 45.42 & 11.46 & 1.44 & 4.30 & 5.12 \\
\hline $\mathrm{B}_{1}\left(2.5 \mathrm{~kg} \mathrm{ha}^{-1}\right)$ & 48.30 & 10.82 & 1.49 & 4.60 & 4.43 \\
\hline$B_{2}\left(5 \mathrm{~kg} \mathrm{ha}^{-1}\right)$ & 49.80 & 11.78 & 1.62 & 4.44 & 4.86 \\
\hline CD at $5 \%$ & 3.49 & NS & 0.10 & 0.18 & 0.49 \\
\hline \multicolumn{6}{|l|}{ Zinc x Boron } \\
\hline $\mathbf{Z}_{0} \mathbf{B}_{0}$ (Control) & 39.57 & 7.97 & 1.15 & 4.20 & 5.13 \\
\hline $\mathrm{Z}_{1} \mathrm{~B}_{1}\left(25 \mathrm{~kg}+2.5 \mathrm{~kg} \mathrm{ha}^{-1}\right)$ & 50.57 & 10.50 & 1.43 & 4.43 & 4.00 \\
\hline $\mathrm{Z}_{1} \mathrm{~B}_{2}\left(25 \mathrm{~kg}+5 \mathrm{~kg} \mathrm{ha}^{-1}\right)$ & 57.47 & 12.37 & 1.68 & 4.27 & 4.70 \\
\hline $\mathrm{Z}_{2} \mathrm{~B}_{1}\left(50 \mathrm{~kg}+2.5 \mathrm{~kg} \mathrm{ha}^{-1}\right)$ & 47.63 & 11.73 & 1.62 & 4.33 & 4.27 \\
\hline $\mathrm{Z}_{2} \mathrm{~B}_{2}\left(50 \mathrm{~kg}+5 \mathrm{~kg} \mathrm{ha}^{-1}\right)$ & 51.87 & 11.63 & 1.60 & 4.93 & 5.60 \\
\hline CD at $5 \%$ & 6.05 & 2.09 & 0.18 & $\mathrm{NS}$ & 0.85 \\
\hline
\end{tabular}

Table.2 Effect of zinc and boron on yield parameters of onion

\begin{tabular}{|c|c|c|c|c|c|}
\hline Treatment & $\begin{array}{l}\text { Bulb Diameter } \\
(\mathrm{cm})\end{array}$ & $\begin{array}{c}\text { Bulb } \\
\text { weight (g) }\end{array}$ & $\begin{array}{l}\text { Shoot: } \\
\text { bulb }\end{array}$ & $\begin{array}{c}\text { Yield } \\
\text { plot }^{-1}(\mathrm{~kg})\end{array}$ & $\begin{array}{c}\text { Yield } \\
\operatorname{ha}^{-1}(\mathbf{q})\end{array}$ \\
\hline \multicolumn{6}{|l|}{ Zinc } \\
\hline $\mathbf{Z}_{0}($ Control $)$ & 5.26 & 76.8 & 0.33 & 3.11 & 138.42 \\
\hline $\mathrm{Z}_{1}\left(25 \mathrm{~kg} \mathrm{ha}^{-1}\right)$ & 6.09 & 96.96 & 0.42 & 4.79 & 212.94 \\
\hline $\mathrm{Z}_{2}\left(50 \mathrm{~kg} \mathrm{ha}^{-1}\right)$ & 6.08 & 89.93 & 0.39 & 4.56 & 202.52 \\
\hline CD at $5 \%$ & 0.25 & 2.95 & $\mathrm{NS}$ & 0.19 & 8.30 \\
\hline \multicolumn{6}{|l|}{ Boron } \\
\hline$\overline{\mathbf{B}_{0}(\text { Control })}$ & 5.23 & 77.03 & 0.34 & 3.58 & 159.26 \\
\hline$B_{1}\left(2.5 \mathrm{~kg} \mathrm{ha}^{-1}\right)$ & 5.94 & 90.33 & 0.38 & 4.22 & 187.51 \\
\hline $\mathrm{B}_{2}\left(5 \mathrm{~kg} \mathrm{ha}^{-1}\right)$ & 6.24 & 96.32 & 0.40 & 4.66 & 207.11 \\
\hline CD at $5 \%$ & 0.24 & 2.95 & NS & 0.19 & 8.30 \\
\hline \multicolumn{6}{|l|}{ Zinc x Boron } \\
\hline $\mathrm{Z}_{0} \mathbf{B}_{0}$ (Control) & 4.40 & 64.20 & 0.27 & 2.31 & 102.66 \\
\hline $\mathrm{Z}_{1} \mathrm{~B}_{1}\left(25 \mathrm{~kg}+2.5 \mathrm{~kg} \mathrm{ha}^{-1}\right)$ & 5.93 & 95.20 & 0.40 & 4.76 & 211.41 \\
\hline $\mathrm{Z}_{1} \mathrm{~B}_{2}\left(25 \mathrm{~kg}+5 \mathrm{~kg} \mathrm{ha}^{-1}\right)$ & 6.83 & 110.80 & 0.48 & 5.32 & 236.59 \\
\hline $\mathrm{Z}_{2} \mathrm{~B}_{1}\left(50 \mathrm{~kg}+2.5 \mathrm{~kg} \mathrm{ha}^{-1}\right)$ & 6.13 & 89.37 & 0.39 & 4.57 & 202.96 \\
\hline $\mathrm{Z}_{2} \mathrm{~B}_{2}\left(50 \mathrm{~kg}+5 \mathrm{~kg} \mathrm{ha}^{-1}\right)$ & 6.30 & 98.40 & 0.37 & 4.96 & 220.30 \\
\hline CD at $5 \%$ & 0.42 & 5.12 & NS & 0.32 & 14.38 \\
\hline
\end{tabular}


Int.J.Curr.Microbiol.App.Sci (2018) 7(4): 3673-3685

Table.3 Effect of zinc and boron on quality parameters of onion

\begin{tabular}{|c|c|c|c|c|c|c|c|c|c|}
\hline \multirow[t]{2}{*}{ Treatment } & \multicolumn{2}{|c|}{$\begin{array}{l}\text { Dry weight/100 g } \\
\text { fresh weight }\end{array}$} & \multirow[t]{2}{*}{$\begin{array}{l}\text { TSS } \\
\left({ }^{0} \mathbf{B}\right)\end{array}$} & \multicolumn{2}{|c|}{$\begin{array}{l}\text { Zinc content } \\
\text { (ppm) }\end{array}$} & \multicolumn{2}{|c|}{$\begin{array}{l}\text { Boron content } \\
(\mathrm{ppm})\end{array}$} & \multicolumn{2}{|c|}{$\begin{array}{l}\text { Sulphur content } \\
(\mathrm{ppm})\end{array}$} \\
\hline & Leaf & Bulb & & Leaf & Bulb & Leaf & Bulb & Leaf & Bulb \\
\hline \multicolumn{10}{|l|}{ Zinc } \\
\hline $\mathbf{Z}_{0}($ Control $)$ & 10.69 & 11.13 & 11.05 & 21.90 & 36.34 & 8.40 & 10.50 & 1871.9 & 1886.3 \\
\hline $\mathrm{Z}_{1}\left(25 \mathrm{~kg} \mathrm{ha}^{-1}\right)$ & 14.26 & 12.93 & 13.10 & 33.20 & 47.51 & 10.50 & 12.69 & 2138.1 & 2068.9 \\
\hline $\mathrm{Z}_{2}\left(50 \mathrm{~kg} \mathrm{ha}^{-1}\right)$ & 15.53 & 12.90 & 13.11 & 33.82 & 47.86 & 9.311 & 11.60 & 2110.3 & 2165.3 \\
\hline CD at $5 \%$ & 3.22 & 0.51 & 0.75 & 1.19 & 1.46 & 0.61 & 0.47 & 73.73 & 85.47 \\
\hline \multicolumn{10}{|l|}{ Boron } \\
\hline$\overline{\mathbf{B}_{0}(\text { Control })}$ & 12.28 & 11.14 & 11.93 & 25.33 & 40.03 & 6.60 & 9.29 & 1949.3 & 1912.4 \\
\hline $\mathrm{B}_{1}\left(2.5 \mathrm{~kg} \mathrm{ha}^{-1}\right)$ & 14.30 & 12.70 & 12.24 & 29.29 & 44.13 & 9.567 & 11.86 & 2051.4 & 2019.1 \\
\hline$B_{2}\left(5 \mathrm{~kg} \mathrm{ha}^{-1}\right)$ & 13.90 & 13.12 & 13.08 & 34.30 & 47.54 & 12.04 & 13.64 & 2119.6 & 2189.0 \\
\hline CD at $5 \%$ & 3.22 & 0.509 & 0.75 & 1.19 & 1.46 & 0.61 & 0.47 & 73.73 & 85.47 \\
\hline \multicolumn{10}{|l|}{ Zinc x Boron } \\
\hline $\mathbf{Z}_{0} \mathbf{B}_{0}($ Control $)$ & 8.60 & 9.80 & 9.77 & 17.97 & 32.73 & 4.80 & 7.17 & 1739.3 & 1801.3 \\
\hline $\mathrm{Z}_{1} \mathrm{~B}_{1}\left(25 \mathrm{~kg}+2.5 \mathrm{~kg} \mathrm{ha}^{-1}\right)$ & 13.63 & 13.0 & 12.70 & 31.23 & 44.63 & 10.13 & 13.07 & 2113.0 & 2019.0 \\
\hline $\mathrm{Z}_{1} \mathrm{~B}_{2}\left(25 \mathrm{~kg}+5 \mathrm{~kg} \mathrm{ha}^{-1}\right)$ & 14.70 & 14.30 & 13.98 & 41.27 & 55.33 & 13.87 & 14.43 & 2120.3 & 2244.7 \\
\hline $\mathrm{Z}_{2} \mathrm{~B}_{1}\left(50 \mathrm{~kg}+2.5 \mathrm{~kg} \mathrm{ha}^{-1}\right)$ & 17.33 & 13.50 & 13.07 & 32.10 & 50.67 & 10.43 & 11.67 & 2116.7 & 2159.0 \\
\hline $\mathrm{Z}_{2} \mathrm{~B}_{2}\left(50 \mathrm{~kg}+5 \mathrm{~kg} \mathrm{ha}^{-1}\right)$ & 15.47 & 13.07 & 12.87 & 38.43 & 48.10 & 10.00 & 11.67 & 2196.7 & 2344.0 \\
\hline CD at $5 \%$ & 5.58 & 0.88 & 1.29 & 2.07 & 2.54 & 1.06 & 0.82 & NS & NS \\
\hline
\end{tabular}

Table.4 Effect of zinc and boron on NPK content in onion

\begin{tabular}{|c|c|c|c|c|c|c|}
\hline \multirow{2}{*}{$\begin{array}{c}\text { Treatment } \\
\text { Zinc }\end{array}$} & \multicolumn{2}{|c|}{$\begin{array}{c}\text { Nitrogen content } \\
(\%)\end{array}$} & \multicolumn{2}{|c|}{$\begin{array}{l}\text { Phosphorus } \\
\text { content (\%) }\end{array}$} & \multicolumn{2}{|c|}{$\begin{array}{l}\text { Potassium } \\
\text { content (\%) }\end{array}$} \\
\hline & Leaf & Bulb & Leaf & Bulb & Leaf & Bulb \\
\hline $\mathbf{Z n}_{0}-$ Control & 0.93 & 1.22 & 0.32 & 0.20 & 1.26 & 1.29 \\
\hline $\mathrm{Zn}_{1}-\mathrm{Zn} @ 25 \mathrm{~kg} \mathrm{ha}^{-1}$ & 1.37 & 1.43 & 0.42 & 0.35 & 1.61 & 1.77 \\
\hline $\mathrm{Zn}_{2}-\mathrm{Zn} @ 50 \mathrm{~kg} \mathrm{ha}^{-1}$ & 1.32 & 1.38 & 0.32 & 0.36 & 1.56 & 1.62 \\
\hline CD at $5 \%$ & 0.14 & NS & NS & 0.12 & 0.17 & 0.21 \\
\hline \multicolumn{7}{|l|}{ Boron } \\
\hline$\overline{\mathbf{B}_{0^{-}} \text {Control }}$ & 1.07 & 1.23 & 0.29 & 0.27 & 1.37 & 1.32 \\
\hline$B_{1}-B @ 2.5 \mathrm{~kg} \mathrm{ha}^{-1}$ & 1.22 & 1.34 & 0.45 & 0.26 & 1.41 & 1.61 \\
\hline $\mathrm{B}_{2^{-}} \mathrm{B} @ 5 \mathrm{~kg} \mathrm{ha}^{-1}$ & 1.33 & 1.46 & 0.31 & 0.38 & 1.65 & 1.74 \\
\hline CD at 5\% & 0.14 & NS & NS & NS & 0.17 & 0.21 \\
\hline \multicolumn{7}{|l|}{ Zinc x Boron } \\
\hline $\mathbf{Z n}_{0}+\mathbf{B}_{0^{-}}$Control & 0.71 & 1.14 & 0.11 & 0.12 & 0.93 & 0.76 \\
\hline $\mathrm{Zn}_{1}+\mathrm{B}_{1}-\mathrm{Zn} @ 25 \mathrm{~kg} \mathrm{ha}^{-1}+\mathrm{B} @ 2.5 \mathrm{kgha}^{-1}$ & 1.37 & 1.48 & 0.29 & 0.22 & 1.33 & 1.74 \\
\hline $\mathrm{Zn}_{1}+\mathrm{B}_{2^{-}} \mathrm{Zn} @ 25 \mathrm{~kg} \mathrm{ha}^{-1}+\mathrm{B} @ 5 \mathrm{~kg} \mathrm{ha}^{-1}$ & 1.49 & 1.60 & 0.58 & 0.47 & 1.77 & 1.85 \\
\hline $\mathrm{Zn}_{2}+\mathrm{B}_{1}-\mathrm{Zn} @ 50 \mathrm{~kg} \mathrm{ha}^{-1}+\mathrm{B} @ 2.5 \mathrm{kgha}^{-1}$ & 1.33 & 1.27 & 0.52 & 0.34 & 1.62 & 1.63 \\
\hline $\mathrm{Zn}_{2}+\mathrm{B}_{2^{-}} \mathrm{Zn} @ 50 \mathrm{~kg} \mathrm{ha}^{-1}+\mathrm{B} @ 5 \mathrm{~kg} \mathrm{ha}^{-1}$ & 1.40 & 1.52 & 0.02 & 0.41 & 1.59 & 1.73 \\
\hline CD at $5 \%$ & NS & NS & NS & NS & 0.29 & 0.37 \\
\hline
\end{tabular}


Table.5 Effect of zinc and boron on fertility status of the soil after harvest

\begin{tabular}{|c|c|c|c|c|c|}
\hline Treatment & \multirow{2}{*}{$\begin{array}{l}\text { A vailable } \\
\text { N (kg/ha) }\end{array}$} & \multirow{2}{*}{$\begin{array}{c}\text { Available } \\
\mathrm{P}_{2} \mathrm{O}_{5} \\
\text { (kg/ha) }\end{array}$} & \multirow{2}{*}{$\begin{array}{c}\text { Available } \\
\mathrm{K}_{2} \mathrm{O} \\
\text { (kg/ha) }\end{array}$} & \multirow{2}{*}{$\begin{array}{c}\text { Organic } \\
\text { carbon } \\
(\%)\end{array}$} & \multirow[t]{2}{*}{ pH } \\
\hline Zinc & & & & & \\
\hline $\mathrm{Zn}_{0}$ - Control & 337.37 & 13.36 & 157.38 & 1.44 & 5.14 \\
\hline $\mathrm{Zn}_{1^{-}} \mathrm{Zn} @ 25 \mathrm{~kg} \mathrm{ha}^{-1}$ & 342.22 & 15.12 & 199.23 & 1.59 & 5.04 \\
\hline $\mathrm{Zn}_{2^{-}} \mathrm{Zn} @ 50 \mathrm{~kg} \mathrm{ha}^{-1}$ & 354.06 & 15.68 & 218.56 & 1.75 & 4.93 \\
\hline CD at $5 \%$ & 9.37 & 0.98 & 12.88 & 0.06 & 0.10 \\
\hline \multicolumn{6}{|l|}{ Boron } \\
\hline $\mathbf{B}_{0^{-}}$Control & 312.45 & 14.17 & 169.02 & 1.55 & 4.99 \\
\hline $\mathrm{B}_{1^{-}} \mathrm{B} @ 2.5 \mathrm{~kg} \mathrm{ha}^{-1}$ & 371.18 & 15.18 & 207.71 & 1.62 & 5.11 \\
\hline $\mathbf{B}_{2^{-}}$B @ $9 \mathrm{~kg} \mathrm{ha}^{-1}$ & 350.03 & 14.81 & 198.43 & 1.61 & 5.02 \\
\hline CD at $5 \%$ & 9.37 & NS & 12.88 & 0.06 & NS \\
\hline \multicolumn{6}{|l|}{ Zinc x Boron } \\
\hline $\mathbf{Z n}_{0}+\mathbf{B}_{0^{-}}$Control & 283.41 & 11.22 & 132.86 & 1.33 & 5.06 \\
\hline $\mathrm{Zn}_{1}+\mathrm{B}_{1}-\mathrm{Zn} @ 25 \mathrm{~kg} \mathrm{ha}^{-1}+\mathrm{B} @ 2.5 \mathrm{~kg} \mathrm{ha}^{-1}$ & 360.08 & 16.10 & 231.53 & 1.61 & 5.13 \\
\hline $\mathrm{Zn}_{1}+\mathrm{B}_{2^{-}} \mathrm{Zn} @ 25 \mathrm{~kg} \mathrm{ha}^{-1}+\mathrm{B} @ 5 \mathrm{~kg} \mathrm{ha}^{-1}$ & 328.11 & 14.26 & 212.04 & 1.42 & 4.93 \\
\hline $\mathrm{Zn}_{2}+\mathrm{B}_{1^{-}} \mathrm{Zn} @ 50 \mathrm{~kg} \mathrm{ha}^{-1}+\mathrm{B} @ 2.5 \mathrm{~kg} \mathrm{ha}^{-1}$ & 377.96 & 15.83 & 212.52 & 1.67 & 4.96 \\
\hline $\mathrm{Zn}_{2}+\mathrm{B}_{2^{-}} \mathrm{Zn} @ 50 \mathrm{~kg} \mathrm{ha}^{-1}+\mathrm{B} @ 5 \mathrm{~kg} \mathrm{ha}^{-1}$ & 368.74 & 14.91 & 223.07 & 2.04 & 5.00 \\
\hline CD at $5 \%$ & 16.22 & 1.70 & 22.30 & 0.11 & NS \\
\hline
\end{tabular}

Table.6 Economics of the treatment

\begin{tabular}{|c|c|c|c|c|c|c|c|}
\hline \multirow[t]{2}{*}{ Treatment } & \multicolumn{3}{|c|}{ Cost of cultivation (Rs. ha ${ }^{-1}$ ) } & \multirow{2}{*}{$\begin{array}{l}\text { Yield } \\
\left(\mathbf{q} \mathbf{h a}^{-1}\right)\end{array}$} & \multirow{2}{*}{$\begin{array}{c}\text { Gross } \\
\text { income @ } \\
\text { Rs.1100 q } \mathbf{q}^{-1}\end{array}$} & \multirow{2}{*}{$\begin{array}{c}\text { Net } \\
\text { income } \\
\left(\text { Rs. Ha }{ }^{-1}\right)\end{array}$} & \multirow{2}{*}{$\begin{array}{l}\text { Benefit: } \\
\text { cost } \\
\text { ratio }\end{array}$} \\
\hline & $\begin{array}{l}\text { Fixed } \\
\text { cost }\end{array}$ & $\begin{array}{l}\text { Treatment } \\
\text { cost }\end{array}$ & Total & & & & \\
\hline $\mathbf{T}_{1}$ - Control & 46,460 & - & 46,460 & 102.66 & 112,926 & 66,466 & $1: 1.43$ \\
\hline $\begin{array}{l}T_{2} \text { - NPK @ 100:60:60 } \mathrm{kg} \mathrm{ha}^{-1}+ \\
\text { FYM @ } 2.5 \mathrm{t}^{-1}+\mathrm{B} @ 2.5 \mathrm{~kg} \mathrm{ha}^{-1}\end{array}$ & 46,460 & 500 & 46,960 & 148.15 & 162,965 & 116,005 & $1: 2.47$ \\
\hline $\begin{array}{l}T_{3} \text { - NPK @ 100:60:60 kg ha }{ }^{-1}+ \\
\text { FYM @ } 2.5 \mathrm{t}^{-1}+\mathrm{B} @ 5 \mathrm{~kg} \mathrm{ha}^{-1} \\
\end{array}$ & 46,460 & 1000 & 47,460 & 164.45 & 180,895 & 133,435 & $1: 2.81$ \\
\hline $\begin{array}{l}T_{4}-\text { NPK @ 100:60:60 kg ha } \\
\text { FYM @ } 2.5 \mathrm{t}^{-1}+\mathrm{Zn} 25 \mathrm{~kg} \mathrm{ha}^{-1}\end{array}$ & 46,460 & 1450 & 47,910 & 190.81 & 209,891 & 161,981 & $1: 3.38$ \\
\hline $\begin{array}{l}T_{5} \text { - NPK @ 100:60:60 } \mathrm{kg} \mathrm{ha}^{-1}+ \\
\text { FYM @ } 2.5 \mathrm{t}^{-1}+\mathrm{Zn} 25 \mathrm{~kg} \mathrm{ha}^{-1}+ \\
\text { B } 2.5 \mathrm{~kg} \mathrm{ha}^{-1}\end{array}$ & 46,460 & 1950 & 48,410 & 211.41 & 232,551 & 184,141 & $1: 3.80$ \\
\hline $\begin{array}{l}T_{6} \text { - NPK @ 100:60:60 kg ha-1 }+ \\
\text { FYM @ } 2.5 \mathrm{t}^{-1}+\mathrm{Zn} 25 \mathrm{~kg} \mathrm{ha}^{-1}+ \\
\text { B } 5 \mathrm{~kg} \mathrm{ha}^{-1}\end{array}$ & 46,460 & 2450 & 48,910 & 236.59 & 260,249 & 211,339 & $1: 4.3$ \\
\hline $\begin{array}{l}T_{7} \text { - NPK @ 100:60:60 } \mathrm{kg} \mathrm{ha}^{-1}+ \\
\text { FYM @ } 2.5 \mathrm{t}^{-1}+\mathrm{Zn} 50 \mathrm{~kg} \mathrm{ha}^{-1} \\
\end{array}$ & 46,460 & 2900 & 49,360 & 184.30 & 202,730 & 153,370 & $1: 3.1$ \\
\hline $\begin{array}{l}T_{8} \text { - NPK @ 100:60:60 } \mathrm{kg} \mathrm{ha}^{-1}+ \\
\text { FYM @ 2.5 } \mathrm{t}^{-1}+\mathrm{Zn} 50 \mathrm{~kg} \mathrm{ha}^{-1}+ \\
\text { B } 2.5 \mathrm{~kg} \mathrm{ha}^{-1}\end{array}$ & 46,460 & 3400 & 49,860 & 202.96 & 223,256 & 173,396 & $1: 3.48$ \\
\hline $\begin{array}{l}\text { T9- NPK @ 100:60:60 } \mathrm{kg} \mathrm{ha}^{-1}+ \\
\text { FYM @ } 2.5 \mathrm{t}^{-1}+\mathrm{Zn} \mathrm{50} \mathrm{kg} \mathrm{ha}^{-1}+ \\
\text { B } 5 \mathrm{~kg} \mathrm{ha}^{-1}\end{array}$ & 46,460 & 3900 & 50,360 & 220.30 & 242,330 & 191,970 & $1: 3.81$ \\
\hline
\end{tabular}


Zinc being an essential component of many enzymes and because of playing a major role in the absorption of moisture, its doses up to certain levels might have increased the content of zinc in the bulbs. Similarly, an increased level of boron increased the boron content, but decreased the zinc contents. Yadav et al., (2006) showed a contradictory effect of zinc and boron in tomato. These results are also in collaboration with Kumar et al., (2007), Chhipa (2005) and Lal (2012). The combination effect between zinc and boron proved to give best results when comparison with single doses of zinc and boron and control in relation with zinc and boron content in leaves but it did not have any significant influence on sulphur accumulation in leaves. Mishra (1990), Rafique and Mahmood-ul-Hassan (2008), Chhipa et al., (2005), Ballabh et al., (2013) and Ali (2013) observed increased contain of total soluble solids (TSS), dry matter content, zinc, boron and sulphur content in onion by application of micronutrients.

It is apparent from the data presented in table 4 that in leaves, highest $\mathrm{N}(1.49 \%), \mathrm{P}(0.58 \%)$ and $\mathrm{K}(1.77 \%)$ was found in $\mathrm{Zn}_{1}+\mathrm{B}_{2}$ ( $\mathrm{Zn} 25$ $\mathrm{kg} \mathrm{ha}{ }^{-1}+\mathrm{B} 5 \mathrm{~kg} \mathrm{ha}^{-1}$ ) while the lowest nitrogen $(0.71 \%)$, phosphorus $(0.11 \%)$ and potassium $(0.93 \%)$ was found under control. The maximum content of nitrogen $(1.60 \%)$, phosphorus $(0.47 \%)$ and potassium $(1.85 \%)$ in bulb was found in $\mathrm{Zn}_{1}+\mathrm{B}_{2}\left(\mathrm{Zn} 25 \mathrm{~kg} \mathrm{ha}^{-1}+\right.$ B $5 \mathrm{~kg} \mathrm{ha}^{-1}$ ) while the lowest nitrogen (1.14\%), phosphorus $(0.12 \%)$ and potassium $(0.76 \%)$ was found under control. Roy (1992) studied the effect of $\mathrm{B}, \mathrm{Zn}$ and $\mathrm{Fe}$ in different combinations and observed that micronutrients enhanced the $\mathrm{N}, \mathrm{P}$ and $\mathrm{K}$ content in rhizome and further reported that application of $\mathrm{Zn}, \mathrm{B}$ and $\mathrm{Fe}$ to ginger resulted increase in the concentration of $\mathrm{N}, \mathrm{P}$ and $\mathrm{K}$ in leaves. The beneficial role of zinc in increasing CEC of roots might have helped in increasing absorption of nutrient from the soil. Further, the beneficial role of $\mathrm{Zn}$ in chlorophyll formation, regulating auxin concentration and its stimulatory effect on most of the physiological and metabolic process of plant, also might have helped plants in absorption of greater amount of nutrients from the soil. Boron is found involved in the availability of nitrogen to the plants and synthesis of cell wall components, hence, increasing level of boron increased the nitrogen content in the bulbs. Mishra et al., (1990) reported that application of borax @10 kg ha ${ }^{-1}$ intensified the magnitude of B uptake in onion bulbs. Similar findings are in concurrent with the works done by Dixit (1997), Suman et al., (2002) and Devi et al., (2009).

The presented in table 5 apparently showed that zinc and boron nutrition gave positive impact on improving the fertility level of the soil. The highest $(2.04 \%)$ organic carbon content in the soil was found in treatment combination $\mathrm{Zn}_{2} \mathrm{~B}_{2}\left(\mathrm{Zn} 50 \mathrm{~kg} \mathrm{ha}^{-1}+\mathrm{B} 5 \mathrm{~kg}\right.$ $\left.\mathrm{ha}^{-1}\right)$ followed by $\mathrm{Zn}_{2} \mathrm{~B}_{1}\left(\mathrm{Zn} 50 \mathrm{~kg} \mathrm{ha}^{-1}+\mathrm{B} 2.5\right.$ $\mathrm{kg} \mathrm{ha}^{-1}$ ) with organic carbon percentage of $1.67 \%$ while the lowest $(1.33 \%)$ was found under control.

The $\mathrm{pH}$ of the soil decreased with application of zinc and boron as the highest $\mathrm{pH}$ of 5.14 was found under control while the lowest $\mathrm{pH}$ of 4.93 was found in $\mathrm{Zn}_{2}\left(\mathrm{Zn} 50 \mathrm{~kg} \mathrm{ha}^{-1}\right)$ and in treatment combination $\mathrm{Zn}_{1}+\mathrm{B}_{2}(\mathrm{Zn} 25 \mathrm{~kg}$ $\mathrm{ha}^{-1}+\mathrm{B} 5 \mathrm{~kg} \mathrm{ha}^{-1}$ ).

The maximum available nitrogen $(377.96 \mathrm{~kg}$ $\mathrm{ha}^{-1}$ ) was found in treatment combination $\mathrm{Zn}_{2}+\mathrm{B}_{1}\left(\mathrm{Zn} 50 \mathrm{~kg} \mathrm{ha}^{-1}+\mathrm{B} 2.5 \mathrm{~kg} \mathrm{ha}^{-1}\right)$ while the maximum available phosphorus $(16.10 \mathrm{~kg}$ $\mathrm{ha}^{-1}$ ) and potassium (231.53 $\left.\mathrm{kg} \mathrm{ha}^{-1}\right)$ was found in $\mathrm{Zn}_{1}+\mathrm{B}_{1}\left(\mathrm{Zn} 25 \mathrm{~kg} \mathrm{ha}^{-1}+\mathrm{B} 2.5 \mathrm{~kg}\right.$ $\mathrm{ha}^{-1}$ ) which were significantly superior to many treatments. The lowest available nitrogen $\left(283.41 \mathrm{~kg} \mathrm{ha}^{-1}\right)$, phosphorus (11.22 $\mathrm{kg} \mathrm{ha}^{-1}$ ) and potassium (132.86 $\left.\mathrm{kg} \mathrm{ha}^{-1}\right)$ was found under control. 
The economics of the fertilizer treatments presented in table 6 revealed that the integrated nutrient management had an appreciable impact on the total yield as well as gross income and net return. The highest net income (Rs.211,339 $\mathrm{ha}^{-1}$ ) with a benefit cost ratio of 1:4.3 was obtained from treatment combination $\mathrm{Zn}_{1}+\mathrm{B}_{2}\left(\mathrm{Zn} 25 \mathrm{~kg}^{-1}\right.$ $+\mathrm{B} 5 \mathrm{~kg} \mathrm{ha}^{-1}$ ) followed by treatment combination $\mathrm{Zn}_{2}+\mathrm{B}_{2}\left(\mathrm{Zn} 50 \mathrm{~kg} \mathrm{ha}^{-1}+\mathrm{B} 5 \mathrm{~kg}\right.$ $\mathrm{ha}^{-1}$ ) with a net income of Rs.191,970 and benefit cost ratio of 1:3.81. The lowest net income of Rs.66,466 with a benefit cost ratio of 1:1.43 was found under control. Most of the treatment combinations were found to increase the net income and benefit cost ratio in comparison to control. The results were in close conformity with the previous work conducted by Kumar and Sen (2005), Chhipa et al., (2005) and Nasreen et al., (2009).

Based on the experimental finding, it can be concluded that soil application of $\mathrm{Zn} 25 \mathrm{~kg}$ $\mathrm{ha}^{-1}+\mathrm{B} 5 \mathrm{~kg} \mathrm{ha}^{-1}$ could improve plant growth parameters, yield and quality characters of onion bulbs under sub-tropical foothill condition. The application of zinc and boron also showed a profound residual effect on sustaining the fertility status of the soil after the harvest. Thus based on the support warranted from the above data, it can be concluded that growing of onions by judicious use of combined application of micro and macro nutrients is the best practice in sustaining productivity and soil health and hence can be practiced by the growers effectively under the foot hills of Nagaland condition.

\section{Acknowledgement}

Authors are thankful to the advisory committee and faculty members of Department of Horticulture (School of Agricultural Sciences and Rural Development, Nagaland University,
Medziphema Campus) and Department of Horticulture (Assam Agricultural University) for their supportive encouragement for the smooth completion of the work.

\section{References}

Acharya, U., Venkatesan, K., Saraswathi, T. and Subramanian, K.S. 2014. Effect of zinc and boron application on growth and yield parameters of Multiplier Onion (Allium cepa L. var. aggregatum Don.) var. CO (On) 5. International Journal of Research, 2: 757-765.

Alam, M.N., Abedin, M.J. and Azad, M.A.K. 2010. Effect of micronutrients on growth and yield of onion under calcareous soil environment. International Research Journal of Plant Science, 1: 56-61.

Ali, S.M.D. 2013. Effects of micronutrients on growth, yield and quality of three varieties of summer onion. M.Sc (Agri) thesis submitted to Bangladesh Agriculture University, Mymensing.

Ballabh, Rana and Rawat, S.S. 2013. Effects of foliar application of micronutrients on growth, yield and quality of onion. Indian Journal of Horticulture, 70(2): 260-265.

Balyan; D.S., Singh, J. and Srivastava, V.K. 1994. Nitrogen and zinc interaction in cauliflower. Crop Research, 8(3): 537542.

Blake, G. R. 1965. Bulk density in methods of soil analysis, Part-I. 374.

Chanchan, M., Hore, J.K. and Ghanti, S. 2013. Response of garlic to foliar application of some micronutrients. Journal of Crop Weed, 9(2):138-141.

Chapman, H.D. and Pratt, P.F. 1961. Methods of Analysis for Soils, Plants and Water. University of California, Division of Agricultural Science, 309.

Chermsiri, C., Watanabe, H., Attajarusit, S., Tuntiwarawit, J. and Kaewaroj, S. 1995. 
Effect of boron sources on onion (Allium cepa L.) productivity. Biology and Fertility of soil, 20(2):125-129.

Chhipa, B.G. 2005. Effect of different levels of sulphur and zinc on growth and yield of cauliflower (Brassica oleracea var. botrytis L.). M.Sc. (Ag.) Thesis, S.K.N. College of Agriculture, Jobner, RAU, Bikaner.

Devi, K.N., Singh, L.N.K., Singh, M.S., Singh, S.B. and Singh, K.K. 2009. Influence of Sulphur and Boron fertilization on yield, quality, nutrient uptake and economics of Soybean (Glycine max) under Upland Conditions. Journal of Agricultural Science, 4(4).

Dixit, H.C. and Singh. V. 1997. Effect of boron and calcium on yield and nutrition of cabbage (Brassica oleracea convar. capitata var. capitata) in Ustipsamment. Indian Journal of Agricultural Sciences, 67(2): 87-88.

Halder, N.K., Ahmed, R., Sharifuzzaman, S.M., Anzu-man-ara bagam, K. and Siddiky, M.A. 2007. Effect of boron and zinc fertilization on corm and cormel production of Gladiolus in grey terrace soils of Bangladesh. International Journal of Sustainable Crop Production, 2(5): 85-89.

Hania, U. 2012. Response of onion to different micronutrients. M.Sc. (Agri) thesis submitted to Bangladesh Agriculture University, Mymensing.

Hansch, R. and Mendel, R.R. 2009. Physiological functions of mineral micronutrients $(\mathrm{Cu}, \mathrm{Zn}, \mathrm{Mn}, \mathrm{Fe}, \mathrm{Ni}, \mathrm{Mo}$, $\mathrm{B}, \mathrm{Cl})$. Current Opinion on Plant Biology, 12: 259-66.

Jackson, M.L. (1967). Soil Chemical Analysis, New Jersey, USA, 199.

Jawarharlal, M. S., Sundararajan and Veeraragavathatham, D. 1986. South Indian Horticulture, 34:236-239.
John, M.K., Chuah, H.H. and Ndufled, J.H. 1975. Application of improved Azomethine-H Method to the determination of Boron in soils and plants. Analytical Letter, 8: 559-568.

Khan, A.A., Zubair, M., Bari, A. and Maula, F. 2007. Response of onion (Allium cepa L.) growth and yield to different levels of nitrogen and zinc in swat valley. Sarhad Journal of Agriculture, 23: 933-36.

Kumar, M. and Sen, N. L. 2005. Effect of zinc boron and gibberellic acid on yield of okra [Ablemoschus esculentus (L.) Moench]. Indian Journal of Horticulture, 62 (3): 308-309.

Kumar, S., Chankhar, S.K. and Rana, M.K. 2007. Response of okra to zinc and boron micronutrients. Vegetable Science, 36(3): 327-331.

Lal Sohan. 2012. Effect of Biofertilizers and Zinc on Growth, Yield and Quality of Sprouting Broccoli (Brassica oleracea var. italica L.). M.Sc (Agri) thesis submitted to the Swami Keshwanand Rajasthan Agricultural University, Bikaner.

Lindsay, W.L. and Norwell, W.A. 1978. Development of DTPA soil test for zinc ion, manganese and copper. Soil Science Society, 42: 421-428.

Manna, D., Maityand, T.K. and Ghosal, A. 2011. Influence of foliar application of boron and zinc on growth, yield and bulb quality of onion (Allium cepa L.). Journal of Crop and Weed, 10(1):53-55.

Marschner, H. 1995. Mineral Nutrition of Higher Plants, Academic Press, New York, 347-364.

Mishra, H.P., Singh K.P. and Yadav, J.P. 1990. Influence of zinc, iron, boron and manganese and uptake on onion (Allium cepa L.) grown in calcareous soil. Haryana Journal of Horticultural Science, 19(12): 153-159. 
Nasreen, S., Yousuf, M. N., Mamun, A. N. M., Brahma, S. and Haquc, M. N. 2009. Response of garlic to zinc, boron and poultry manure application. Bangladesh Journal of Agricultural Research, 34(2): 239-245.

Palaskar, M.S., Babrekar, P.G. and Ghosh, A.B. 1981. A rapid analytical technique to estimate sulphur in soil and plant extracts. Journal of the Indian Society of Soil Science, 29: 249- 256.

Panse, V.G. and Sukhatme, P.U. 1978. Statistical Methods for Agricultural Workers. Indian Council of Agriculture Research, New Delhi, 145-152.

Prasad, S. and Kumar, U. 2010. Principles of Horticulture, Agrobios Publication, 211.

Quddus, M.A., Rashid, M.H, Hossain, M.A. and Naser, H.M. 2009. Effect of Zinc and Boron on yield and yield contributing characters of Mungbean in low Ganges River Floodplain soil at Madaripur, Bangladesh. Bangladesh Journal of Agricultural Research, 1(36).

Rafique and Mahmood-ul-Hassan, M. 2008. Zinc nutrition of onion: proposed diagnostic Criteria. Journal of Plant Nutrition, 31(21): 307-316.28.

Sindhu, S.S. and Tiwari, S.S. 1993. Effect of micro-nutritents on yield and quality of onion (Allium cepa L.) cv. Pusa Red. Progressive Horticulture, 25(3-4): 176180.

Singh, A.K. and Ram, H. 2001. Effect of phosphorus and zinc on yield and quality of mungbean. Annals of Plant and Soil Research, 3(2): 307-309.
Singh, K.P., Singh, V.K., Kamalkant and Roy, R.K. 2005. Effect of different levels of boron and its methods of application on growth and yield of cauliflower (Brassica oleracea var. botrytis L.). Vegetable Science, 38(1): 76-78.

Sisler, E.C., Dagger, W.M. and Gauch, H.G. 1956. The role of Boron in translocation of organic compounds in plants. Plant Physical, 13: 11-17.

Srivastava, R., Agarwal, A., Tiwari, R.S. and Kumar, S. 2005. Effect of micronutrients, zinc and boron on yield, quality and storability of garlic (Allium sativum). Indian Journal of Agricultural Sciences, 75(3): 157-159.

Suman, S., Kumar, R. and Singh, S.K. 2002. Effect of sulphur and boron nutrition on growth, yield and quality of onion (Allium cepa L.) Patna. Indian Journal of Applied Biology, 12(1/2): 40-46.

Thakare, R.G., Jadhao, B.J., Nandre, D.R., Ghawade, S.M. and Khewale, P. 2007. Effect of zinc and iron levels on growth and yield of potato. Indian Journal of Plant Archives, 7(1):275-276.

Trivedi, A.P. and Dhumal, K.N. 2005. Effect of application of zinc and iron on growth, yield, and quality of onion (Allium cepa L.). Bangladesh Journal of Agricultural Research, 38(1): 41-48.

Yadav, R. A., Tripathi, A. K. and Yadav, A. K. 2006. Effect of micronutrients in combinations with organic manures on production and net returns of sesame (Sesamum indicum) in Bundelkhand tract of Uttar Pradesh. Anuual Agricultural Research, 30 (1/2) 53- 58.

\section{How to cite this article:}

Khatemenla, V.B. Singh, Trudy Tengse A. Sangma and Maiti, C.S. 2018. Effect of Zinc and Boron on Growth, Yield and Quality of Onion (Allium cepa L.) cv. Agrifound Dark Red. Int.J.Curr.Microbiol.App.Sci. 7(04): 3673-3685. doi: https://doi.org/10.20546/ijcmas.2018.704.413 